\section{Progesterone Biosynthesis by Equine Granu- losa Cells growing in Tissue Culture}

OuR knowledge of the pathways of steroid biosynthesis in the ovary has been gained mainly by incubations of ovaries in vitro ${ }^{1,2}$. The tissues incubated have contained numerous cell types: granulosa cells, theca interna cells, stromal cells, interstitial cells, and sometimes luteal cells. Possibly such mixtures of two or more different cell types are able to secrete hormones that one cell type cannot secrete by itself ${ }^{3-3}$. Furthermore, during such incubations in vitro an exchange of precursors and products between different cell types may be facilitated because of breakdown of naturally occurring barriers, such as the basement membrane between the granulosa layer and the theca interna of the follicle.

Thus there is clearly a need for more information on the steroidogenic potential of individual cell types studied in isolation. The purpose of the present experiments was to explore the possibility of growing a corpus luteum in tissue culture from a pure cell line, namely the granulosa cells, and to determine whether or not such a tissue is capable of steroid synthesis.

Graafian follicles, $2-6 \mathrm{~cm}$ in diameter, were dissected out of equine ovaries which had been collected at various stages of the oestrous cycle, by a method previously described $^{3}$. The granulosa cells were scraped out under aseptic conditions. Vital staining with eosin $Y$ (ref. 10) and nigrosin ${ }^{11}$ demonstrated that only 10-20 per cent of the granulosa cells were alive. The cells were grown at $37^{\circ} \mathrm{C}$ as stationary monolayers, either on glass coverslips placed in test-tubes or in $50-\mathrm{ml}$. glass bottles. Microscopically, the cultures appeared to consist of one celltype only. The growth medium used consisted of 10 per cent horse serum, 30 per cent medium 199 (ref. 12), and 60 per cent Hanks's balanced salt solution ${ }^{12}$. After various incubation times the coverslip preparations were washed with warm Hanks's solution, fixed in Bouin's solution, and stained with haematoxylin and eosin For some experiments, various radioactive steroid hormones in propylene glycol were added to the medium. The old medium together with any dead cells was dis. carded before addition of fresh medium containing the steroids.

Regardless of the stage of the oestrous cycle of the mare, granulosa cells removed from vascular follicles were found to adhere to the glass forming monolayers, and to take on within 2-4 days many of the morphological features which are characteristic of luteal cells. The cytoplasm of these cells increased in amount and became more densely stained and granular in appearance; the nucleus increased in size, and the chromatin material became more distinct and abundant. Some mitoses were also to be seen. This luteinization process occurred irrespective of whether gonadotrophin was added to the medium.

It has been possible to show that these cultured granulosa cells are capable of steroid synthesis. Thirty-two vessels, sixteen with gonadotrophin added (5 I.U./ml. of a mixture of pregnant mares' serum and human chorionic gonadotrophin) and sixteen without gonadotrophin, were incubated for an average of 7 days. The media were pooled, a small amount of $7-{ }^{3} \mathrm{H}$-progesterone added as an internal recovery standard, and a $224-\mathrm{ml}$. sample extracted with ether in the presence of alkali; the ether extract was chromatographed on paper in a ligroin/80 per cent methanol system ${ }^{13}$.

The paper chromatogram revealed a large amount of progesterone, which was further characterized by the following criteria: (i) same $R_{F}$ value on paper and same gas chromatographic retention time on $3 \cdot 8$ per cent $S . E$. 30 as authentic progesterone; (ii) absence of acetylable hydroxyl groups; (iii) infra-red spectrum identical to that of authentic progesterone; (iv) formation, on treatment with $20 \beta$-hydroxysteroid dehydrogenase ${ }^{14}$, of a compound with paper and gas chromatographic properties identical with those of authentic 20ß-hydroxypregn-4-en-3-one; the sulphuric acid: 80 per cent ethanol chromogen ${ }^{15}$ of this compound showed the expected peak at $478 \mathrm{mu}$; its acetylation product had the same paper and gas chromatographic properties as that of $20 \beta$-acetoxypregn4-en-3-one. Control medium in which cells were not grown contained no detectable steroids.

It was calculated that the $340 \mu \mathrm{g}$ of progesterone isolated from the medium had been formed by $20,000-40,000$ live cells in the course of the 7-day culture period. In addition the medium also contained appreciable amounts of $20 \alpha$-hydroxypregn-4-en-3-one $(89 \mu \mathrm{g}), 17 \alpha$-hydroxyprogesterone $(35 \mu \mathrm{g})$, androstenedione $(35 \mu \mathrm{g})$, and a trace of oestradiol $(>2 \mu \mathrm{g})$. Contrary to Falck's observations in the rat ${ }^{7,8}$ and Short's observations in the horse ${ }^{3,4,6}$, it appears that equine granulosa cells by themselves are capable of some androgen and oestrogen biosynthesis in tissue culture whon gonadotrophin is present.

When the 7- or 14-day-old cultures were incubated for $24 \mathrm{~h}$ with $10 \mu \mathrm{c} .16^{-3} \mathrm{H}$-pregnenolone $(15 \mu \mathrm{c} . / \mu \mathrm{g})$, more than 90 per cent of the steroid was metabolized-the major product being progesterone. The specific activity of the progesterone so formed was only half that of the starting material, which can be taken as further evidence for the de novo synthesis of progesterone by these colls.

The pattern of pregnenolone metabolism by the luteinized granulosa cells was similar to that obtained with cultures of equine corpora lutea. Thus it seems as if equine granulosa cells really can develop into a corpus luteum in tissue culture. Surprisingly, they can do so regardless of the stage of the follicle from which they were obtained, and quite irrespective of the presence of gonadotrophin in the culture medium. It remains to be seen whether gonadotrophins can augment the secretory activity or prolong the life-span of such a test-tube corpus luteum.

I thank the National Institutes of Health and the Agricultural Research Council for financial aid. I also thank Dr. R. Short for providing laboratory space and helpful advice, and Dr. T. Mann for his co-operation and Mr. J. Stansfield of Unicam for carrying out the infra-red analysis.

\section{Cornelia P. Channing}

Department of Veterinary Clinical Studies, University of Cambridge.

${ }^{1}$ Savard, K., Marsh, J. M., and Rice, B. F., Rec. Prog. Hormone Res., 21, 285 (1965).

2 Ryan, K. J., and Smith, O. W., Rec. Prog. Hormone Res., 21, 367 (1965).

${ }^{3}$ Ryan, K. J., and Short, R. V., Endocrinology, 76, 108 (1965).

4 Ryan, K. J., and Short, R. V., Endocrinology, 78, 214 (1966).

"Mahajan, D. K., and Samuels, L. T., Fed. Proc., 22, 2214 (1963).

'Short, R. V., Rec. Prog. Hormone Res., 20, 303 (1964).

' Falck, B., Acta Physiol. Scand., 47, Suppl. 163 (1959).

${ }^{8}$ Falck, B., Menander, K., and Nordanstedt, O., Nature, 193, 593 (1962).

- Bjersing, L., and Carstensen, H., Biochim. Biophys. Acta, 86, 639 (1964).

${ }^{10}$ Hanks, J. H., and Wallace, J. H., Proc. Soc. Exp. Biol. Med., 98, 188 (1958).

${ }^{11}$ Kaltenbach, J. P., Kaltenbach, M. H., and Lyons, W. B., Exp. Cell Res., 15 $112(1958)$.

${ }^{12}$ Parker, R., Methods of Tissue Culture, third ed. (Hoeber, Inc., New Sork, 1961).

${ }^{13}$ Short, R. V., J. Endocrinol., 22, 153 (1961)

${ }^{14}$ Henning, H. O., and Zander, J., Hoppe Seyle's Zeit. Physiol. Chem., 330, 31 (1962).

${ }^{15}$ Wiest, W. G., J. Biol. Chem., 234, 3115 (1959).

\section{Trimethylamine- $\mathbf{N}$-oxide Biosynthesis in the Bullfrog}

THE comparative aspects of the mechanism of oxygenations dependent on molecular oxygen have recently been investigated using the biosynthesis of trimethylamine-Noxide as a model ${ }^{1}$. That investigation raised a number of questions beyond the presence of the enzymatic activity in a given organism. In the case of the bullfrog, Rana catesbeiana, questions which remained were: the intra- 